\title{
練菌における高度不飽和脂肪酸含有リン脂質の生理機能 Physiological Roles of Phospholipids Containing Polyunsaturated Fatty Acids in Bacteria
}

\author{
川本 純 \\ 京都大学化学研究所 \\ T 611-0011 \\ 京都府宇治市五ヶ庄 \\ Jun KAWAMOTO \\ Institute for Chemical Research, \\ Kyoto University \\ Gokasho, Uji, Kyoto 611-0011, Japan
}

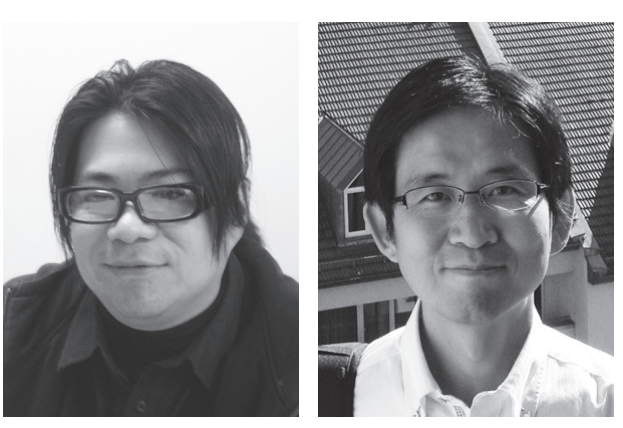

栗原 達夫

京都大学化学研究所

T 611-0011

京都府宇治市五ヶ庄

Tatsuo KURIHARA

Institute for Chemical Research,

Kyoto University

Gokasho, Uji, Kyoto 611-0011, Japan

論文要旨:エイコサペンタエン酸 (EPA) やドコサヘキサエン酸などの長鎖多価不飽和脂肪酸 (PUFA) は, 多様な生理活性を示す必須脂肪酸である。生体膜を構成するリン脂質のアシル鎖として存在する PUFA は 膜の物理化学的特性を変化させることで, 周辺の膜タンパク質の機能発現に関与していることが予想される が, PUFAの機能発現機構の詳細は明らかではない。一方で, 極地周辺や深海などの低温環境から単離さ れた海洋性細菌の多くがPUFA を生産することが知られている。近年, 高等生物に比べて単純な構造の細 胞を形成するこれらの微生物を用いた研究により, PUFA が従来知られていなかった生理的役割を担って いることが明らかとなってきた。本稿では, 南極海水より単離された低温菌における EPA生合成機構と, 本菌の環境適応における EPA の生理機能について紹介する。

\begin{abstract}
Long-chain polyunsaturated fatty acids (PUFA), such as eicosapentaenoic acid (EPA) and docosahexaenoic acid, are essential fatty acids for human, which provide various favorable effects on health, including anti-inflammatory and anti-tumor effects. PUFA-containing phospholipids change the physicochemical properties of biological membranes and might modulate the function of membrane proteins. However, it is not fully understood how PUFA exerts their function. EPA and DHA are found in various bacteria isolated from cold environments, such as Polar Regions and deep sea, and are synthesized as an acyl chain of their membrane phospholipids. By using these bacteria, which have much simpler cell structure than eukaryotes, it was demonstrated that PUFA plays novel physiological roles in their environmental adaptation. Here, we describe the biosynthesis mechanism of EPA and its physiological role in cold adaptation of a bacterium isolated from Antarctic seawater. We propose that EPAcontaining phospholipids support the function of membrane proteins involved in cell division and membrane transport at low temperatures as a hydrophobic chemical chaperone.
\end{abstract}

Key words: polyunsaturated fatty acid, eicosapentaenoic acid, phospholipid, membrane microdomain, cell division

\section{1 はじめに}

エイコサペンタエン酸 (EPA) やドコサヘキサエン 酸（DHA）に代表される $\omega 3$ 系長鎖多価不飽和脂肪酸 （PUFA）は，非共役の二重結合を 5〜6 個有する機能性 脂質である。多くの臨床研究や疫学的調査の結果, EPA P DHA の $\omega 3$ 系 PUFA は抗炎症作用や抗腫瘍作

連絡者：栗原 達夫

E-mail : kurihara@scl.kyoto-u.ac.jp
用をもち, また, 動脈硬化症や脳溢血などの血管性疾患 の発症リスクを低減することが示されている ${ }^{1-3)}$ 。また, アラキドン酸などの $\omega 6$ 系脂肪酸も含めて, PUFAは, 生理活性物質であるプロスタグランジンやトロンボキサ ンといったエイコサノイドの前駆体としても重要な脂肪 酸である ${ }^{4)}$ 。ヒトは, EPA や DHA を de novo 合成する 仕組みを有しておらず, PUFA の前駆体となる $\alpha$-リノ レン酸や, EPA もしくは DHA そのものを摂取する必 要がある ${ }^{5)}$ 。PUFA は，天然ではイワシやサバなどの青 
背の魚の油の中に多く存在し，積極的な摂取が推奨され ている。一方で, 海洋性微細藻類であるラビリンチュラ 類や，極地や深海といった低温・高圧環境から単離され

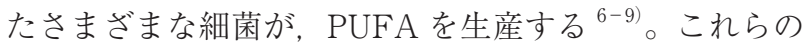
細菌については, 低温・高圧適応にPUFA が重要な役 割を担っていることが示されている ${ }^{10-12)}$ 。ヒトや細菌 において, PUFA は細胞膜を構成するリン脂質のアシ ル鎖として存在することがわかっており, 周辺の膜タン パク質の機能発現に関与していることが予想されるが, 膜タンパク質の機能発現における PUFAの生理的役割 には不明な点が多い。本稿では，南極海水由来の EPA 産生細菌をモデル生物として行った研究を紹介し, 生体 膜におけるPUFA の生理機能について論じる。

\section{2 細菌の PUFA 生合成機構}

植物や線虫, 糸状菌においては, 通常の脂肪酸合成経 路を介して合成されるパルミチン酸（16：0）やステア リン酸（18：0）を前駆体として EPA が生合成される。 これらの飽和脂肪酸を前駆体とし, 脂肪酸伸長酵素と不
飽和化酵素（デサチュラーゼ）の働きによる伸長反応と 二重結合の挿入反応が進行することで， $\alpha$-リノレン酸 や EPA が合成される ${ }^{5)}$ 。デサチュラーゼによる不飽和 化反応には分子状酸素が必須となる。一方, PUFAを 生産する細菌は, 上述の PUFA 産生生物とは全く異な る経路を有している。矢澤らにより, 細菌の EPAの生 合成には，ポリケチド合成酵素の類縁タンパク質群を コードする遺伝子クラスターが必須であることが明らか となった ${ }^{13)}$ 。 EPA 産生細菌である Shewanella pneumatophore SCRC-2738 に は, orf2, orf5, orf6, orf7, orf8 の 5 つの遺伝子で構成される EPA 生合成遺 伝子クラスターが存在する。これらの遺伝子は他の PUFA 産生細菌にも存在し, これらにコードされる生 合成タンパク質群には，脂肪酸の生合成に関与すること が予想される種々の酵素活性ドメインが保存されている ことから，これらのドメインが触媒する連続的な反応に よって EPA が生合成されると推測されている(Fig. 1)。

筆者らは，EPA 生合成タンパク質群による PUFA 生 成機構の解明に取り組んでいる ${ }^{14)}$ 。南極海水より単離

(a)

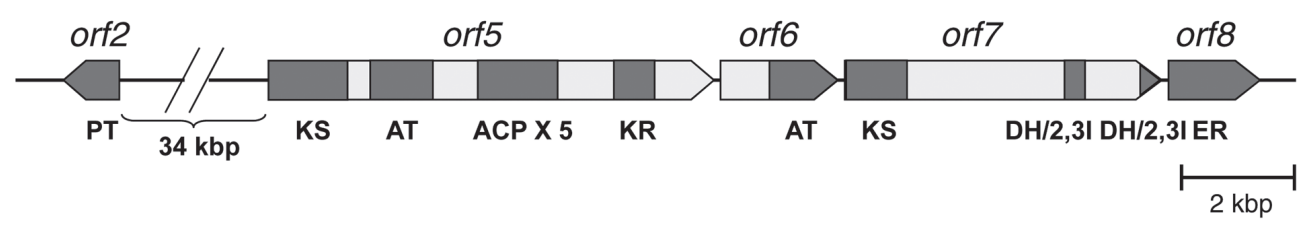

(b)

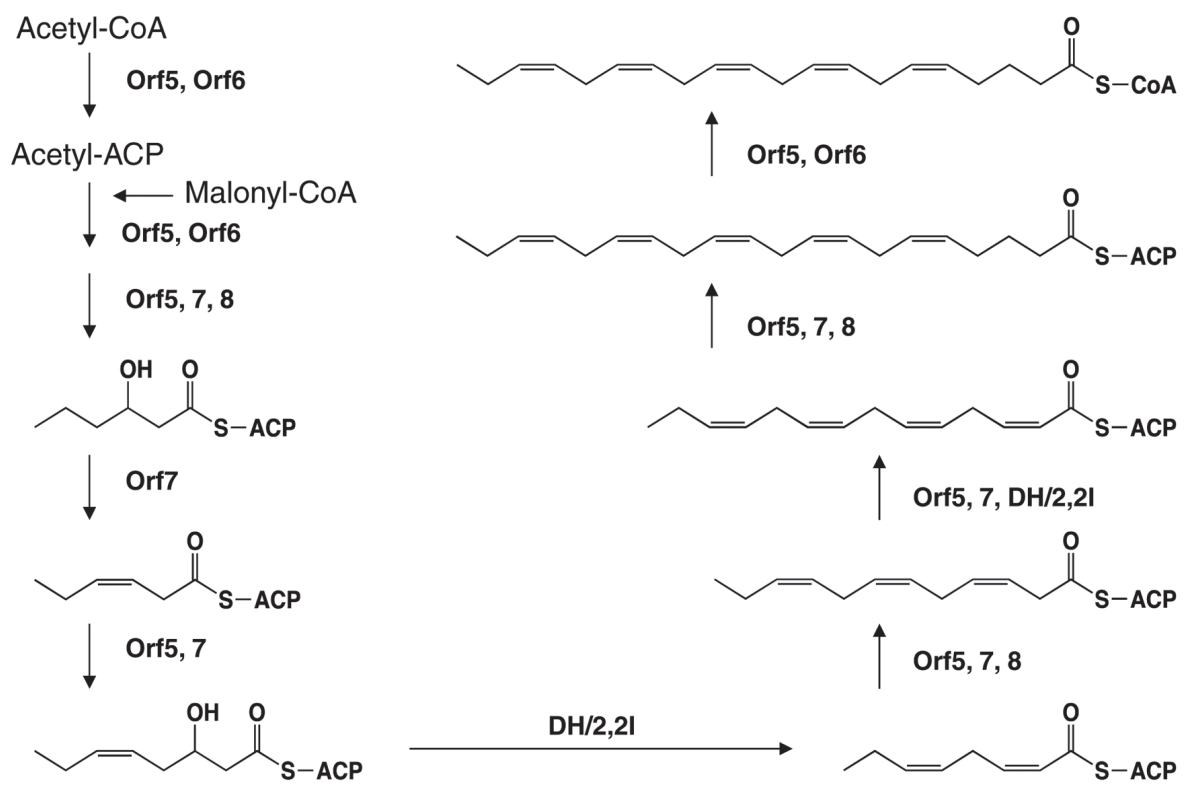

Fig. 1 細菌における EPA 生合成遺伝子群と生合成経路

(a) 南極海水より採取された好冷性細菌 Shewanella livingstonensis Ac10 の EPA 生合成遺伝子群。各遺伝子がコードするタンパ ク質に保存されている酵素活性ドメインをグレーで示している。PT：ホスホパンテテイニル基転移酵素，KS：3-ケトアシ ル合成酵素, AT：アシル基転移酵素, ACP：アシルキャリヤータンパク質, KR：3-ケトアシルレダクターゼ, DH：デヒド ラターゼ，2，3I：2-trans-3-cisイソメラーゼ，ER：エノイルレダクターゼ。

（b）細菌の EPA 生合成遺伝子群にコードされるタンパク質群による EPA 生合成の予想経路。各矢印に, 各反応を触媒する $\mathrm{EPA}$ 生合成タンパク質を示している。 
された好冷性細菌 Shewanella livingstonensis Ac10 は $4^{\circ} \mathrm{C}$ から $25^{\circ} \mathrm{C}$ で生育し, $18^{\circ} \mathrm{C}$ で最も良好に生育する。本 菌を低温 $\left(4^{\circ} \mathrm{C}\right)$ で培養すると, 低温誘導的に全脂肪酸 の 5〜10\%を占める $\mathrm{EPA}$ が生産されるが, $18^{\circ} \mathrm{C}$ で培養 したときにはEPA はほとんど検出されない。本菌のゲ ノム解析から, EPAの生合成に関与することが予想さ れる遺伝子クラスターを見いだした Fig. 1)。筆者らは, $\mathrm{EPA}$ 生合成タンパク質群の諸性質を解析し, 本菌にお ける EPA 生合成機構の解明を試みた。5つの EPA 生合 成遺伝子のうち, orf2 はホスホパンテテイニル基転移 酵素（PPTase）をコードしており，補酵素 A（CoA） のホスホパンテテイニル基を, アシルキャリヤータンパ ク質（ACP）のセリン残基に転移することで, ACP の ホロ化を触媒することが予想された（Fig. 2)。また， orf5には 5 つの ACP ドメインが保存されていたことか ら, Orf2 は Orf5の ACP ドメインにホスホパンテティ ニル基を転移するPPTase である可能性が示唆された。 組換え型 Orf2 を精製するとともに, orf5にコードされ ている5つの ACP ドメインを個別に発現・精製し, Orf2によるホスホパンテテイニル基の転移を解析し た。その結果, Orf2 は CoA 依存的に Orf5の ACP ドメ インをホスホパンテテイニル化することが示された。 EPA の生合成には Orf5 に存在する 5 つの ACP ドメイ ンのいずれもが関与している可能性が示された。以上の 結果から，本菌における EPA生合成は，Orf2による Orf5の ACP ドメインのホスホパンテテイニル化が初発 段階であり, Orf5の ACP ドメインに導入されたホスホ パンテテイニル基のチオール基が脂肪酸生合成の足場と なるものと考えられた。

\section{EPA 生合成遺伝子欠損株をもちいた EPA の生理機 能解析}

EPA や DHA の生合成遺伝子クラスターは, Shewanella 属細菌のほか, 深海より単離されたPhotobacterium profundum SS9 や Colwellia psychrerythraea 34H, 海洋 性のシアノバクテリア (Phaeodactylum tricornutum) など, 低温・高圧環境から採取された様々な海洋性微生 物に保存されていることから, 微生物の低温・高圧環境 適応にPUFA 生産が重要な役割を担っていることが予 想される ${ }^{8,9,15-17)}$ 。二重結合を多くもつ EPA や DHA は, 飽和脂肪酸に比べて顕著に融点が低いことから, 低温環 境における生体膜の流動性に寄与している可能性が考え られるが, 低温・高圧環境適応微生物における PUFA 生産能の生理的役割を解析した例は少ない。

筆者らは, S. livingstonensis Ac10への外来遺伝子の 導入法, および本菌の遺伝子破壊法を確立している ${ }^{11,18)}$ 。 本菌における EPAの生理的役割を解明するために, 5 つの EPA 生合成遺伝子それぞれの破壊株を作製した。 $\mathrm{EPA}$ 生合成遺伝子破壊株は, 低温での EPA 生産能を欠 失していたことから，上述の 5 つの EPA 生合成遺伝子 は, いずれも本菌の EPA生産に必須であることがわかっ た。 $\mathrm{EPA}$ を生産できない遺伝子変異株（ $\mathrm{E} \mathrm{EPA})$ は,

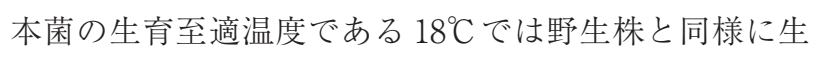

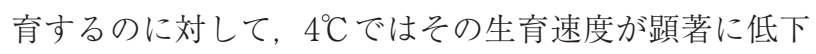
していた（Fig. 3）。化学合成した EPA 含有リン脂質を 培養液に添加した結果, $\Delta \mathrm{EPA}$ の生育速度の低下が抑制 されたことから, EPA は本菌の低温での生育に重要な 脂肪酸であることが示された。EPAの久損による低温 での生育速度の低下は, 本菌の細胞膜の流動性の低下に

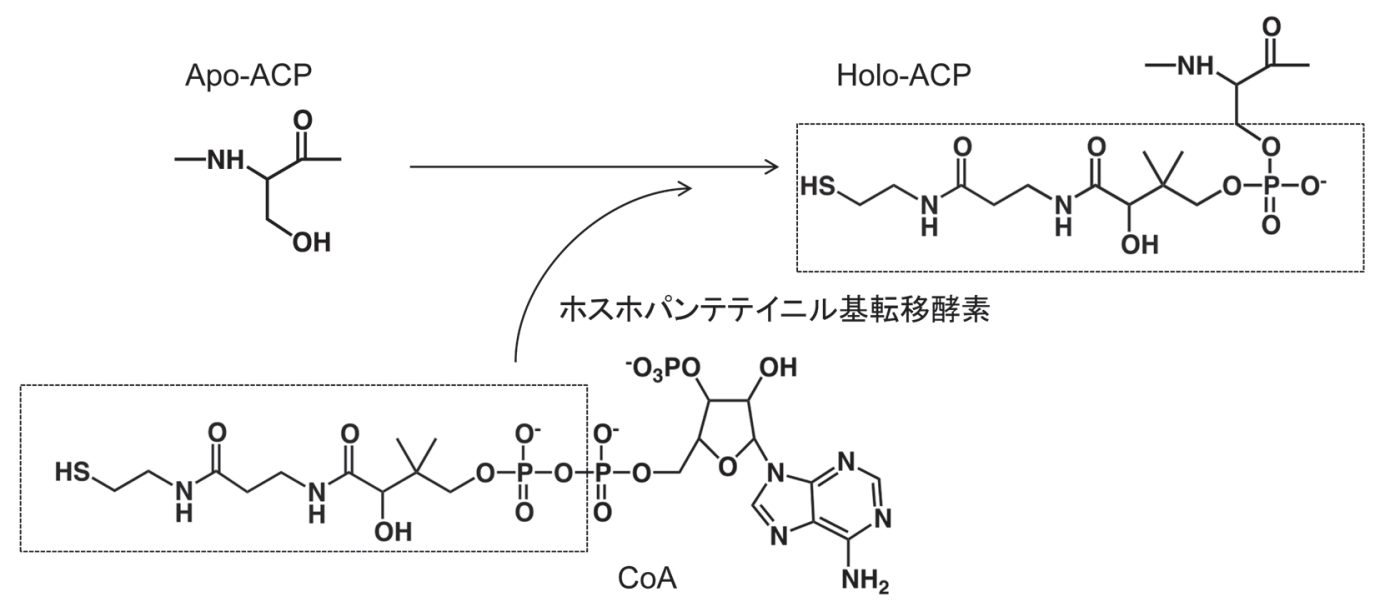

Fig. 2 ホスホパンテテイニル基転移酵素によるアシルキャリヤータンパク質の修飾

EPA 生合成遺伝子群のうち, orf 2 はホスホパンテテイニル基転移酵素をコードしており， orf 5 がコードする EPA生合成足場夕 ンパク質のアシルキャリヤータンパク質ドメインのセリン残基にホスホパンテテイニル基を転移する。 

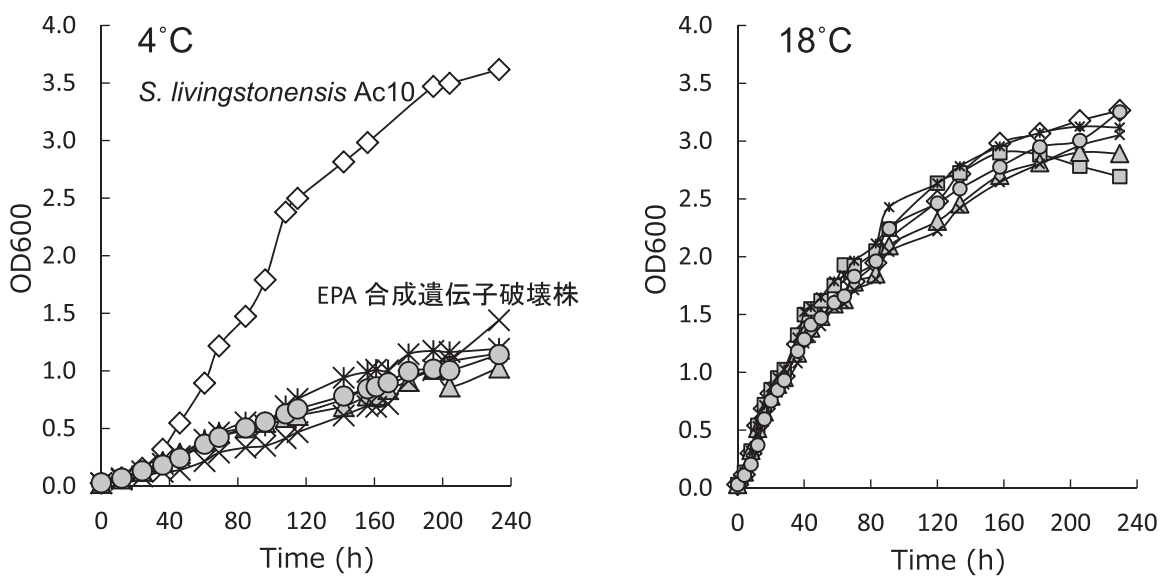

Fig. 3 S. livingstonensis Ac10 の EPA 欠損株の生育特性

$4^{\circ} \mathrm{C}$ (左) と $18^{\circ} \mathrm{C}$ (右) における生育曲線。 $\diamond$ : 野生株, $\square$ : orf2 久損株, $\triangle$ : orf5 欠損株, $\times:$ orf6 欠損株, * * orf7 欠損株, : orf8 欠損株。

よる可能性が考えられたことから，筆者らは疎水性蛍光 プローブ (ピレン) の膜における側方拡散を解析するこ とで, EPAの欠損が細胞膜の流動性におよぼす影響を 評価した。対照実験としてEscherichia coliの細胞膜流 動性も測定した。その結果, S. livingstonensis Ac10 はE. coliに比べて，流動性の高い生体膜を形成していること がわかった。一方で，EPA 欠損株におけるピレンの拡 散性は，野生株と顕著な差はないことが示されたことか ら, EPAの有無は本菌の膜流動性には大きく影響しな いことがわかった。本菌では，モノ不飽和脂肪酸である パルミトレイン酸（16：1）が全脂肪酸の約 40\%を占め ていることから，モノ不飽和脂肪酸を含むリン脂質が膜 全体の融点を低く保つことで，低温でも流動的な生体膜 を構築しているものと考えられた。一方，EPAの欠損 は膜流動性への影響は小さいことから，本菌において EPA は低温での膜流動性の維持以外の役割を担ってい る可能性が示唆された。

低温での $\Delta \mathrm{EPA}$ の形態を解析した結果, 野生株に比 べ顕著に伸長した細胞を形成していることが見いだされ た。EPAを $s n-2$ 位に導入した合成リン脂質を培養液に 添加したとき， $\Delta \mathrm{EPA}$ は野生株と同様の 1〜2 $\mu \mathrm{m}$ の短 桿状の菌体を形成したことから，本菌の低温での細胞分 裂に EPA が関与することが推定された。細菌の細胞分 裂は, 細胞の中心部に約 12 種のタンパク質で構成され る細胞分裂装置が形成されることで開始し, 核様体の複 製・分離，隔壁形成と細胞膜分離が進行する。 $\mathrm{EPA}$ は, 一つの細胞内に核様体が複数存在する多核細胞を形成し ていた。さらに， $\triangle \mathrm{EPA} の$ 細胞内には通常のグラム陰性 細菌には存在しない異常な膜構造が発達していたことか ら（Fig. 4)，EPAの欠損は本菌の細胞分裂における核 様体の分離以降の段階，つまり新規に合成される細胞膜

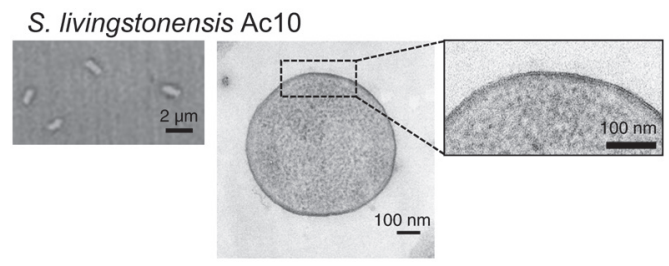

EPA 欠損株

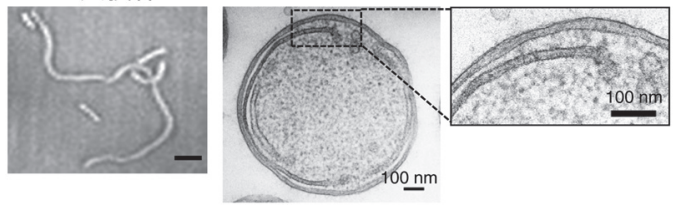

Fig. 4 EPA 欠損株の形態と細胞内微細構造

野生株（上）と EPA 欠損株（下）の光学顕微鏡像と超薄切 片の電子顕微鏡像。電子顕微鏡像の四角で囲んだ箇所を拡大 し，それぞれの右側に示した。

成分の膜への組み込みと隔壁形成の段階に異常をきたす ものと考えられた。さらに， $\Delta \mathrm{EPA} の$ 細胞膜タンパク質 のプロテオーム解析を行うことで, EPAの欠損により 生産量が変動する膜タンパク質を探索した結果, 細胞膜 を介した可溶性分子の輸送に関与する外膜拡散チャンネ ルタンパク質の生産量が減少していることが見いだされ た。低温環境下では, 水の粘性が増加するため, 本菌は 低温誘導的に外膜拡散チャンネルタンパク質を生産する と考えられるが ${ }^{19)}$, EPAの欠損は, これら低温で重要 な生理的機能を担う膜タンパク質の生産量に影響してい ることが示された。以上の結果から, S. livingstonensis Ac10の低温環境適応において, EPA は従来考えられて きた膜流動性の維持ではなく, 細胞分裂後期における適 切な細胞膜構造の形成, および膜輸送タンパク質の生合 成に重要な役割を担っていることが示された。

一方で, 本菌と近縁の Shewanella marinintestina 
IK-1においては，EPA などの長鎖多価不飽和脂肪酸は 細胞外の過酸化物質に対する防御機構として抗酸化の役 割を担っていることが報告されている ${ }^{20)}$ 。また, 深海 由来のP. profundum SS9 では, EPA 欠損が低温・高 圧適応に影響をおよぼさなかったことから ${ }^{9)}$ ，PUFAの 低温での膜タンパク質機能発現への関与は, 特定の好冷 性細菌に限定される可能性も考えられる。どのような細 胞においてPUFA が細胞分裂や膜タンパク質機能発現 に関与しているか明らかにすることは今後の課題である が, PUFA が重要な生理的役割を担うS. livingstonensis Ac10 は, PUFA の生理機能解析に有用なモデル生物と みなすことができる。

\section{EPA アナログ含有リン脂質をもちいた長鎖多価不飽 和脂肪酸の構造 - 機能相関の解析}

S. livingstonensis Ac10の $\Delta \mathrm{EPA} に$ に EPAを含有す る合成リン脂質を添加することで, 低温での生育速度の 低下と伸長した細胞の形成は抑制された。二重結合の数 や位置が異なるPUFAs を含むリン脂質で同様の効果が 見られるか検討した ${ }^{12)}$ 。二重結合の数が異なる炭素鎖 長 20 の脂肪酸および DHA を $s n-2$ 位に導入したリン脂 質を合成し（Fig. 5)， $\Delta \mathrm{EPA}$ の培養液に添加して，本菌 の低温での生育と細胞形態を解析した（Fig. 6)。EPA もしくはDHAを含有するリン脂質を添加した場合,

(a)

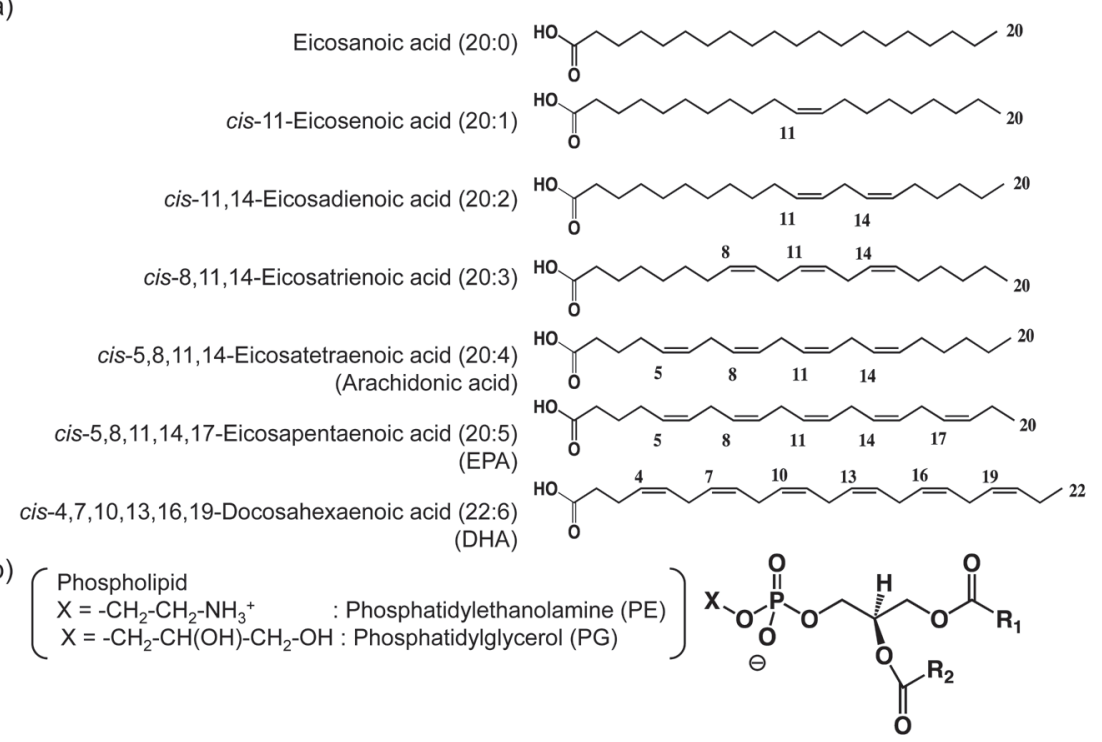

(a) 炭素鎖長 20 の長鎖脂肪酸と DHA。

Fig.5ＥPA アナログ含有リン脂質の構造

(b) リン脂質の構造。EPA アナログ含有リン脂質は, $s n-1$ 位 $\left(\mathrm{R}_{1}\right)$ にオレイン酸, $s n-2$ 位に $\left(\mathrm{R}_{2}\right)$ の EPAのアナログを導入した。

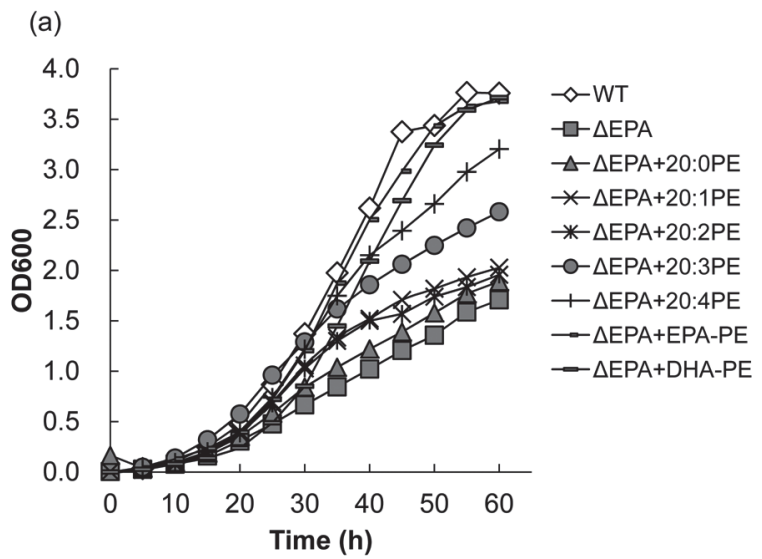

(b)

\begin{tabular}{lc} 
& $(\mu \mathrm{m})(\mathrm{n}=20)$ \\
\hline $\mathrm{WT}$ & $2.1 \pm 0.5$ \\
$\triangle \mathrm{EPA}$ & $4.2 \pm 2.4$ \\
$\triangle \mathrm{EPA}+20: 0 \mathrm{PE}$ & $5.8 \pm 3.6$ \\
$\triangle \mathrm{EPA}+20: 1 \mathrm{PE}$ & $13.6 \pm 8.5$ \\
$\triangle \mathrm{EPA}+20: 2 \mathrm{PE}$ & $10.4 \pm 8.1$ \\
$\triangle \mathrm{EPA}+20: 3 \mathrm{PE}$ & $7.2 \pm 5.3$ \\
$\triangle \mathrm{EPA}+20: 4 \mathrm{PE}$ & $2.5 \pm 1.1$ \\
$\triangle \mathrm{EPA}+\mathrm{EPA}-\mathrm{PE}$ & $1.9 \pm 0.6$ \\
$\triangle \mathrm{EPA}+\mathrm{DHA}-\mathrm{PE}$ & $1.8 \pm 0.5$ \\
\hline
\end{tabular}

Fig. 6 EPA アナログ含有リン脂質を添加したS. livingstonensis Ac10 の EPA 欠損株の生育特性

(a) $4{ }^{\circ} \mathrm{C}$ での EPA アナログ含有リン脂質存在下における EPA 欠損株 $(\Delta \mathrm{EPA})$ の生育曲線。 EPA アナログ含有リン脂質は, $s n-1$ 位にオレオイル基（18：1）, sn-2 位に EPAの構造アナログを有する。

(b) EPA アナログ含有リン脂質存在下における $\Delta \mathrm{EPA}$ の平均細胞長。 
$\Delta \mathrm{EPA}$ は野生株と同様に生育し, 約 $2 \mu \mathrm{m}$ の菌体を形成 した。興味深いことに, DHA 含有リン脂質存在下で培 養した $\Delta \mathrm{EPA}$ のリン脂質組成を解析した結果, EPA 含 有リン脂質が合成されていることがわかった。本変異株 は EPAの de novo 合成能を欠損していることから，添 加したリン脂質中の DHA を EPA に変換する仕組みを 有しているものと考えられた。本実験では，DHAが EPAの生理機能を代替できるか，明らかにすることは できなかったが，DHA が EPAに変換されたという結 果は, 本菌の低温適応において, 特にEPA が重要な分 子であることを示唆している。一方，二重結合の数が異 なる EPA アナログ含有リン脂質を添加した場合，二重 結合の数が減少するにしたがって， $\Delta \mathrm{EPA} の$ 生育速度の 低下と，伸長した細胞の形成を抑制する効果が弱まっ た。アラキドン酸 (20：4）やエイコサトリエン酸（20： 3）などに比べて, EPA が本菌の低温適応機構に, より 適した分子であることが明らかとなった。

\section{PUFA 動態解析用プローブの開発と局在性解析}

筆者らは，本菌の細胞膜における $\mathrm{EPA}$ の動態を可視 化するために，極性頭部を蛍光標識した EPA 含有リン
脂質の合成を試みた ${ }^{21)}$ 。細菌の細胞膜リン脂質の炭化 水素鎖はエステル結合を介してグリセロール骨格に結合 しているため， $s n-2$ 位にエステル結合を介して EPAを 導入したリン脂質を合成し，菌体に添加したが，アシル 鎖の交換反応によって EPA が蛍光プローブから遊離す るため,このような交換反応を受けないプローブの設計 が必要となった。培養液に添加された合成リン脂質は,

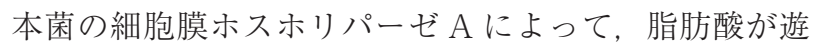
離し，脂質リモデリング経路に組み込まれると予想され たことから，ホスホリパーゼ A によって $\mathrm{EPA}$ が遊離し ないプローブ分子（エーテル結合を介してエイコサペン 夕エニル基がグリセロール骨格に結合し，極性頭部が 4-fluoro-7-nitrobenzofurazan（NBD）で蛍光標識された $N$-NBD-1-oleoyl-2-eicosapentaenyl-sn-glycero-3phosphoethanolamine (acylalkyl-EPA)) を合成した (Fig. 7)。Acylalkyl-EPA $\Delta \mathrm{EPA}$ に添加した結果, 菌体中 央の細胞分裂部位に蛍光シグナルが局在することがわ かった。 $s n-2$ 位にオレイル基（18：1）を導入した蛍光 リン脂質を添加した場合には，局在化した蛍光シグナル は検出されなかったことから，本菌は細胞分裂サイトに EPA 含有リン脂質が濃縮したマイクロドメインを形成

(a) Acylalkyl-OLA
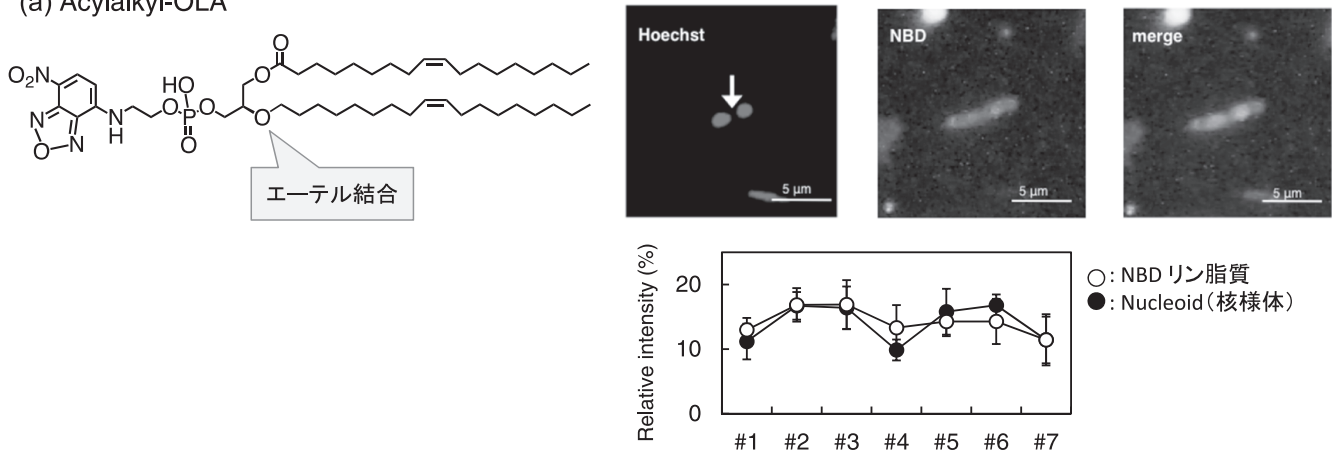

(b) Acylalkyl-EPA
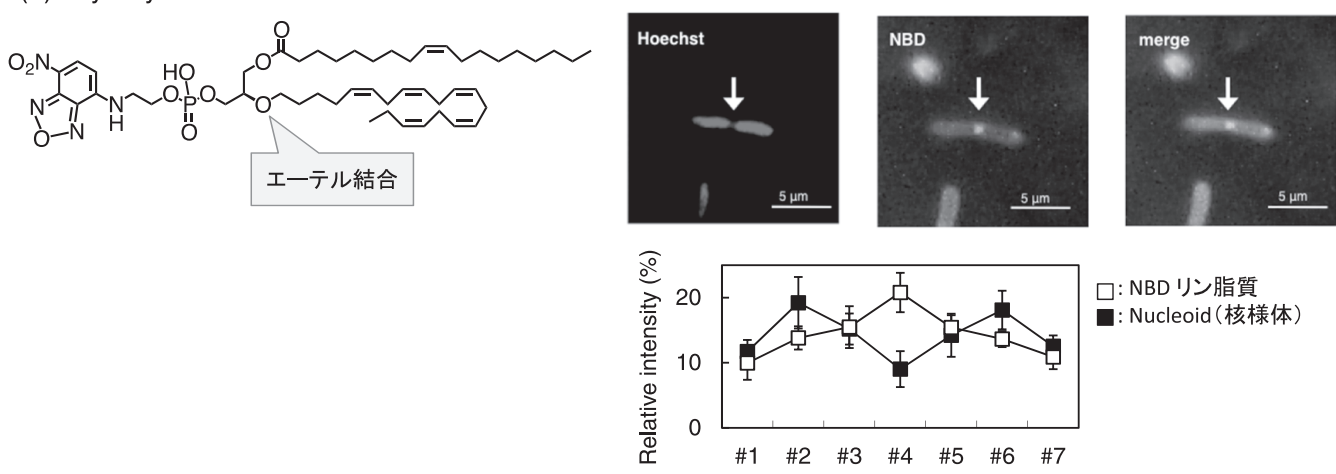

Fig. 7 蛍光標識したエーテル型リン脂質の構造とS. livingstonensis Ac10に抢けるEPA 含有マイクロドメインの形成 極性頭部を NBD で蛍光標識したリン脂質の構造を示す。リン脂質の $s n-2$ 位にエーテル結合を介してオレイル基(Acylalkyl-OLA)

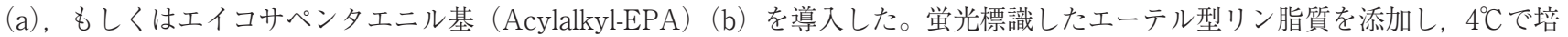
養した菌体の蛍光顕微鏡像を右側に示す。核様体は Hoechst で染色した。7 区画に分けた細胞内における Hoechst，および NBD 由来の蛍光強度の分布を，グラフで示している。Acylalkyl-EPA の場合，蛍光が核様体閉鎖部位に局在した。 
しているものと考えられた。還元剤をもちいた NBDの 消光実験の結果から, 細胞内膜の内葉に到達した EPA 含有リン脂質が細胞分裂サイトに濃縮されることが示唆 された。EPA 生合成遺伝子破壊株の解析から, 本菌の 低温での細胞分裂に EPA が重要な機能を有しているこ とが示されており，本実験で明らかとなったマイクロド メインの存在は, 本菌の細胞分裂装置と EPA との相互 作用の存在を強く示唆している。EPA が局在化したド メインは, 他の脂肪酸を含む膜とは顕著に物理化学的特 性が異なることが予想され，細胞分裂において局所的に 曲率の高い膜の形成に関与している可能性が示唆され た。さらに, 細菌の細胞分裂サイトは細胞膜形成に関わ る多様な夕ンパク質が協調して機能する場であることか $ら^{22)}, \mathrm{EPA}$ が, これら膜タンパク質の低温での機能発
現に重要であることが予想された。

\section{6 膜タンパク質の機能発現における EPA の役割}

S. livingstonensis Ac10の低温環境適応機構において, EPA は膜の流動性の維持ではなく, 低温での細胞分裂 や膜を介した物質輸送に関与する膜タンパク質の適切な 機能発現に重要であることが予想された。筆者らは, 外 膜チャンネルタンパク質 (OmpA) のホモログである Omp74 と EPA との相互作用に着目した ${ }^{23)}$ 。低温で培 養した野生株において Omp74 は少なくとも二種類の構

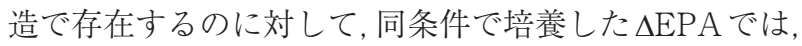
Omp74 はその構造多様性を失っていることがわかった (Fig. 8)。以上の結果は, Omp74の生体膜での構造形成 に EPA が関与することを示唆していたことから，その

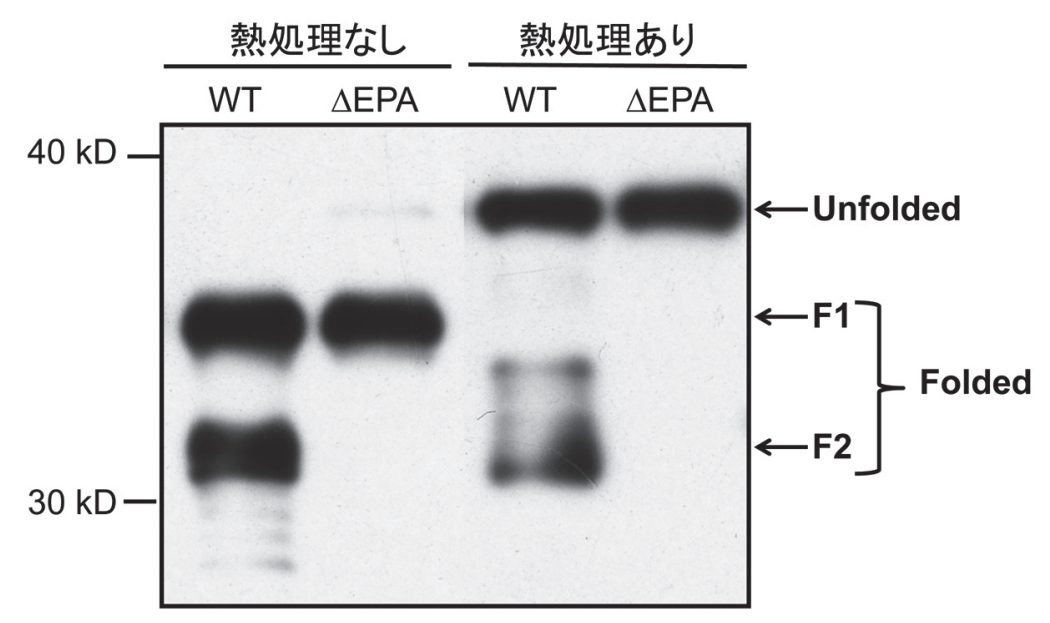

Fig. 8 S. livingstonensis Ac10 に㧍ける外膜チャンネルタンパク質のフォールディング解析 $4^{\circ} \mathrm{C}$ で培養したS. livingstonensis Ac10 および EPA 欠損株（ ンブロット解析によるin vivo フォールディングの解析。野生株において, Omp74 は F1, F2 の二種類のフォールディング状態 にある。 $\Delta \mathrm{EPA}$ では, F1のみが検出される。
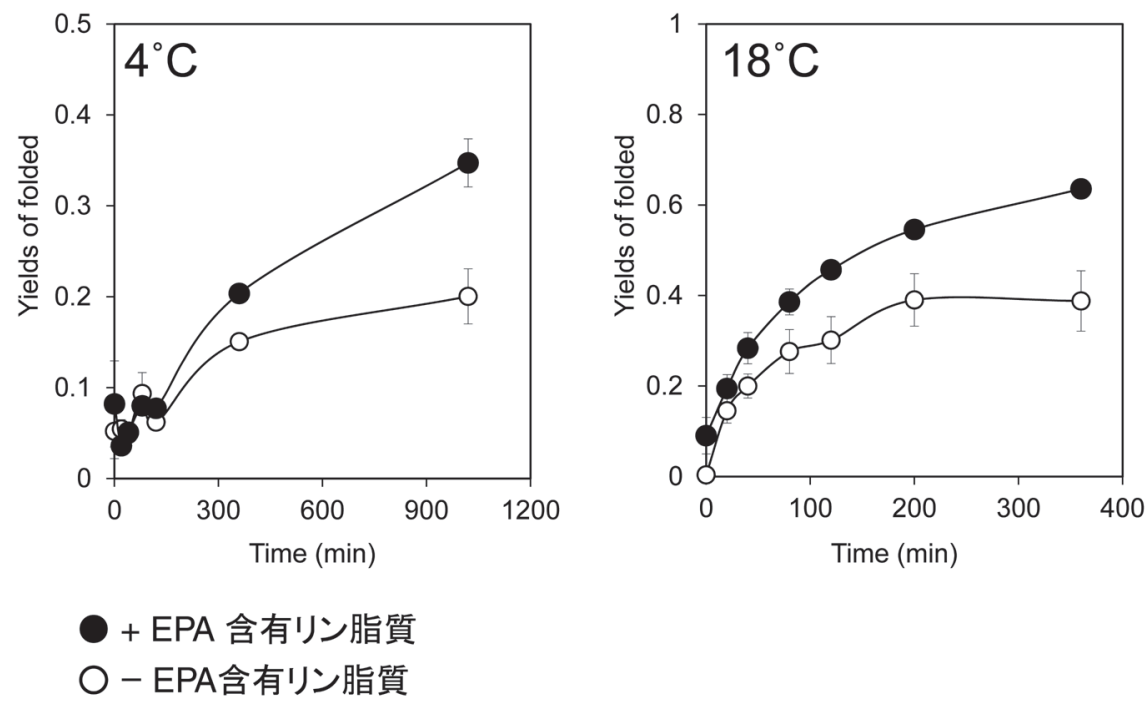

Fig. 9 EPA 含有リン脂質によるOmp74 のフォールディング促進 
可能性を検証するため, EPAを含む合成リン脂質をも ちいた Omp74の in vitroリフォールディング系を構築 した。その結果, EPA 含有リン脂質存在下で, Omp74 の膜表層との相互作用，および，疎水的環境での $\beta$ - シー 卜形成と高次構造形成が促進されたことから，EPAは Omp74 の低温での構造形成を促進する機能を有してい ることが明らかとなった（Fig. 9）。Feller らによる計算 科学的解析から, 非共役の二重結合に挟まれた C-C 結 合の回転は, 飽和脂肪酸の C-C 結合に比べてエネルギー 障壁が小さいことが報告されており，非共役二重結合を 多数有する EPA や DHA は, 疎水的環境において多様 な構造を形成する脂肪酸であると考えられている ${ }^{24)}$ 。

リン脂質のアシル鎖の構造多様性は周辺膜タンパク質表 面の凹凸に対して容易にフィットすることから, 膜タン パク質の生体膜への溶媒和を向上させることで, 膜夕ン パク質の膜への挿入や膜内での構造変化を促進させてい ると考えられる。本菌においては, 水の粘性が増加し膜 の流動性が低下する低温環境で, EPA 含有リン脂質を 誘導生産し，EPA が局在化したマイクロドメインを形 成することで, 膜タンパク質の効率的な機能発現を促進 していると予想され, EPA が本菌の膜において分子シャ ペロン様の生理的役割を担う分子であることが示唆され た。

\section{7 まとめ}

EPA や DHA のような長鎖多価不飽和脂肪酸 (PUFA) は，抗腫瘍作用や抗炎症作用をもつとともに，さまざま な血管性疾患の予防の効果をもつなど, ヒトの健康維持 に有効な脂質として認識されており，EPA や DHA を 含む食品の積極的な摂取が推奨されている。一方で, EPA はプロスタグランジンやトロンボキサンといった エイコサノイドの前駆体として長く注目されてきた分子 である。このような脂肪酸は, 細胞膜を構成するリン脂 質のアシル鎖として存在するが, PUFA 含有リン脂質 自体の機能発現機構の詳細は明らかでない。筆者らは, 高等生物の細胞に比べて単純な構造をもつ細菌をモデル 生物としてPUFA 研究に取り組んできた。南極海水よ り単離された EPA 産生微生物 S. livingstonensis Ac10 は，低温での生育に EPA を必要とする特殊環境微生物 である。筆者らは，本菌の EPA 生合成遺伝子を破壊す ることで作製した EPA 欠損株と，さまざまなアシル鎖 を含む合成リン脂質をもちいた解析から， EPA が本菌 の細胞分裂や物質輸送に関連する膜タンパク質の機能発 現を促進している可能性を見いだした。特に, EPA 含 有リン脂質が脂溶性の分子シャペロンとして, 膜タンパ ク質の構造形成を促進することは，これまでのPUFA
研究では報告されていない新たな機能といえる。また, 本菌で見いだされた EPA 含有リン脂質を含むマイクロ ドメインの存在は, 他の生物の細胞においてもPUFA 含有リン脂質が局在化したマイクロドメインがさまざま な生理機能を担っている可能性を示すものである。 PUFA 含有リン脂質が局在化するマイクロドメインに おけるPUFA と膜タンパク質の相互作用の詳細など, 今後解明されるべき点が多く存在するが，本菌や他の細 胞において PUFA 含有リン脂質が形成するマイクロド メインに着目した研究が展開されることにより, PUFA 研究に新たなパラダイムがもたらされることが期待され る。

\section{文 献}

1) Albert, C. M. et al. Fish consumption and risk of sudden cardiac death. JAMA, 279, 23-8 (1998).

2) Birch, E. E., Garfield, S., Hoffman, D. R., Uauy, R. \& Birch, D. G. A randomized controlled trial of early dietary supply of long-chain polyunsaturated fatty acids and mental development in term infants. Dev. Med. Child. Neurol., 42, 174-81 (2000).

3) Dewey, A., Baughan, C., Dean, T., Higgins, B. \& Johnson, I. Eicosapentaenoic acid (EPA, an omega-3 fatty acid from fish oils) for the treatment of cancer cachexia. Cochrane Database Syst. Rev., CD004597 (2007).

4) Serhan, C. N., Chiang, N. \& Van Dyke, T. E. Resolving inflammation: dual anti-inflammatory and pro-resolution lipid mediators. Nat. Rev. Immunol., 8, 349-61 (2008).

5) Wallis, J. G., Watts, J. L. \& Browse, J. Polyunsaturated fatty acid synthesis: what will they think of next? Trends Biochem. Sci., 27, 467-73 (2002).

6) Kumon, Y. et al. A new labyrinthulid isolate that produces only docosahexaenoic acid. Mar. Biotechnol. $(N Y)$, 8, 170-7 (2006)

7) Kato, C. \& Nogi, Y. Correlation between phylogenetic structure and function: examples from deep-sea Shewanella. FEMS Microbiol. Ecol., 35, 223-230 (2001).

8) Rodrigues, D. F. \& Tiedje, J. M. Coping with our cold planet. Appl. Environ. Microbiol., 74, 1677-86 (2008).

9) Allen, E. E., Facciotti, D. \& Bartlett, D. H. Monounsaturated but not polyunsaturated fatty acids are required for growth of the deep-sea bacterium Photobacterium profundum SS9 at high pressure and low temperature. Appl. Environ. Microbiol., 65, 1710-20 (1999).

10) Kawamoto, J. et al. Favourable effects of eicosapentaenoic acid on the late step of the cell division in a piezophilic bacterium, Shewanella violacea DSS12, at highhydrostatic pressures. Environ. Microbiol., 13, 2293-8 (2011).

11) Kawamoto, J. et al. Eicosapentaenoic acid plays a beneficial role in membrane organization and cell division 
of a cold-adapted bacterium, Shewanella livingstonensis Ac10. J. Bacteriol., 191, 632-40 (2009).

12) Sato, S. et al. Cold adaptation of eicosapentaenoic acidless mutant of Shewanella livingstonensis Ac10 involving uptake and remodeling of synthetic phospholipids containing various polyunsaturated fatty acids. Extremophiles, 12, 753-61 (2008).

13) Metz, J. G. et al. Production of polyunsaturated fatty acids by polyketide synthases in both prokaryotes and eukaryotes. Science, 293, 290-3 (2001).

14) Gong, C., Kawamoto, J., Esaki, N. \& Kurihara, T. Functional analysis of an eicosapentaenoic acid biosynthesis protein Orf2 from a psychrotrophic bacterium, Shewanella livingstonensis Ac10. Trace Nutrients Research, 29, 84-91 (2012).

15) Methe, B. A. et al. The psychrophilic lifestyle as revealed by the genome sequence of Colwellia psychrerythraea $34 \mathrm{H}$ through genomic and proteomic analyses. Proc. Natl. Acad. Sci. U S A, 102, 10913-8 (2005).

16) Nogi, Y., Kato, C. \& Horikoshi, K. Taxonomic studies of deep-sea barophilic Shewanella strains and description of Shewanella violacea sp. nov. Arch. Microbiol., 170, 331-8 (1998).

17) Yongmanitchai, W. \& Ward, O. P. Growth of and omega-3 fatty acid production by Phaeodactylum tricornutum under different culture conditions. Appl. Environ. Microbiol., 57, 419-25 (1991).

18) Miyake, R. et al. Construction of a low-temperature protein expression system using a cold-adapted bacterium, Shewanella sp. strain Ac10, as the host. Appl. Environ. Microbiol., 73, 4849-56 (2007).

19) Kawamoto, J., Kurihara, T., Kitagawa, M., Kato, I. \& Esaki, N. Proteomic studies of an Antarctic cold-adapted bacterium, Shewanella livingstonensis Ac10, for global identification of cold-inducible proteins. Extremophiles, 11, 819-26 (2007).

20) Okuyama, H., Orikasa, Y. \& Nishida, T. Significance of antioxidative functions of eicosapentaenoic and docosahexaenoic acids in marine microorganisms. Appl. Environ. Microbiol., 74, 570-4 (2008).

21) Sato, S. et al. Occurrence of a bacterial membrane microdomain at the cell division site enriched in phospholipids with polyunsaturated hydrocarbon chains. $J$. Biol. Chem., 287, 24113-21 (2012).

22) Weiss, D. S. Bacterial cell division and the septal ring. Mol. Microbiol., 54, 588-97 (2004).

23) Dai, X. Z., Kawamoto, J., Sato, S. B., Esaki, N. \& Kurihara, T. Eicosapentaenoic acid facilitates the folding of an outer membrane protein of the psychrotrophic bacterium, Shewanella livingstonensis Ac10. Biochem. Biophys. Res. Commun., 425, 363-7 (2012).

24) Feller, S. E. \& Gawrisch, K. Properties of docosahexaenoic-acid-containing lipids and their influence on the function of rhodopsin. Curr. Opin. Struct. Biol., 15, 416-22 (2005). 